Irish Math. Soc. Bulletin

Number 73, Summer 2014, 5-19

ISSN 0791-5578

\title{
MATHEMATICS EDUCATION AND THE PUBLIC'S INTERACTION WITH THE HAMILTON STORY
}

\author{
FIACRE Ó CAIRBRE
}

\begin{abstract}
The life and works of William Rowan Hamilton have produced a lot of public interest over many years. Consequently, Hamilton's story has contributed greatly to mathematics education in relation to the general public. This paper illustrates the wide diversity of ways that the general public has interacted with the Hamilton story.
\end{abstract}

\section{INTRODUCTION}

This paper discusses some of the rich diversity of public interactions with the Hamilton story and also illustrates the wide appeal of the Hamilton story in the general public. The main motivation for this article comes from the fact that many people, mainly from outside mathematics, frequently contact me wishing to know about Hamilton and then many of them want to create something related to Hamilton. Consequently, the list of art works, media events, activities and more, related to Hamilton has been growing a lot over the years. I felt it was time to write about this abundance of items related to Hamilton and also to write about some of the background stories. In writing this article, I decided to go back the whole way rather than just cover what was done during my time. As you will see, many people have been inspired by the Hamilton story to create works of art. Such people include poets, sculptors, painters, novelists, a songwriter and many more. Hamilton's life and works have been written about in many places. For those who wish to read more about Hamilton, see [1], [2], [3], [4], [5], [7]. In particular, the story about his creation of quaternions along the banks of the Royal Canal on October 16, 1843, appears in many of the examples of the public's interaction with Hamilton below.

I also believe that many of the items in the list below are connected to mathematics education in relation to the general public. From

Received on 9-5-2014, revised 28-5-2014.

(c)2014 Irish Mathematical Society 
my experience in promoting mathematics in the general public, I find that the Hamilton story (and other stories from the history of mathematics) often changes people's perception of mathematics for the better. I believe this change of perception can be crucial in any form of positive mathematics education because after the change in perception, people are then more likely to enhance their understanding, awareness and appreciation of mathematics. I see this happening frequently when I promote mathematics in the general public. Also, the general public plays a significant part in mathematics education in second and third level because parents, policy makers and the media are all members of the general public and can exert great influence on the attitude of young people and society at large towards mathematics. Jack Gannon, from Cabra, put it well when he said, "On account of the walk, Hamilton is in the folk consciousness of the local people".

I find that the "big picture" approach is very successful in changing people's perception of mathematics for the better [6]. The Hamilton story (combined with the annual Hamilton walk) is a great example of something that has all the big picture items. Some of the big picture items are, in no particular order: history of mathematics, stories, human element and famous characters, beauty, drama, motivation, practical power and applications, freedom, creativity, Irish connection, outdoor activity, research, word origins, humour, deductive reasoning, abstraction, cultural connections, tricks/magic and puzzles.

The fact that about half of the items in the list below relate to the last ten years shows that the Hamilton story is alive and very vibrant today. Also, it's a great example of something from the history of mathematics that continues to inspire people (many of whom are outside mathematics) to respond to the story. The response can take different forms including the creation of works of art.

The criterion for inclusion in the list below is that (a) the item was created by somebody outside mathematics or (b) the item (or the main part of the item) is easily accessible to the general public or (c) there is a good chance that the general public will interact with the item. The reason for this criterion is that I am looking at the Hamilton story in relation to the general public. Consequently, there are many important and interesting mathematical items related to 
Hamilton that are not on the list below. I also decided to omit many fine books that contain chapters or sections about Hamilton even if they are accessible to the general public, because there are just too many such books.

\section{Public interactions with the Hamilton Story}

1. 1830 - Thomas Kirk sculpted a marble bust of Hamilton. It was acquired by the National Gallery of Ireland in 1982. It's interesting to note that Hamilton was only 25 in 1830. The curator of the National Gallery of Ireland, Brendan Rooney, told me that the bust is currently in storage. Typically, only about a quarter of the gallery's pieces are on public display and the rest are in storage. However, the bust was part of a public exhibition in the National Gallery recently.

2. 1833 - Terence Farrell executed a bust of Hamilton. A picture of this bust appears in the frontispiece of [1].

3. 1842 - There was a portrait of Hamilton in the Dublin University Magazine.

4. 1865 - Shortly before his death, Hamilton was elected as the First Foreign Associate of the newly established National Academy of Sciences of the US. This meant that the Academy deemed Hamilton to be the greatest living scientist.

5. 1867 - John Henry Foley sculpted a bust of Hamilton. This bust is on display in the Long Room in Trinity College.

6. 1882 - 1891 Robert Graves wrote a biography of Hamilton in three volumes [1].

7. 1894 - The Royal Irish Academy acquired a portrait of Hamilton. It was an oil painting by Sarah Purser and was donated by Hamilton's descendant, John O'Regan. Hamilton was President of the RIA from 1837 to 1846. The RIA librarian, Petra Schnabel, also told me that there is a bust of Hamilton in the RIA. However, it's not known who sculpted the bust or when it was done.

8. 1910 - A statue of Hamilton was finished in the Royal College of Science in order to be ready for the College's inauguration in 1911. The statue is now in a niche on the facade of Government Buildings on Merrion St. If you stand on Merrion St. and look through the 
gates, you will see Hamilton on the left in the distance. The statue was designed by Oliver Sheppard and executed, at least in part, by an anonymous Bavarian sculptor.

9. 1924 - Éamon De Valera scratched Hamilton's quaternion formulas on the wall of his prison cell when he was in Kilmainham jail. He was paying homage to Hamilton who scratched the quaternion formulas on the bridge in Cabra on October 16, 1843. I suppose one could say that Hamilton's action was, "One small scratch for a man, one giant leap for mathematics", because his quaternions liberated algebra from the shackles of arithmetic. Hamilton opened up a whole new landscape in mathematics. Also, there are many applications of quaternions today, including computer animation, computer games, special effects in movies, space navigation and much more. There is no trace of De Valera's formulas. However, in 1966, when he visited Kilmainham jail, he wrote the quaternion formulas on an envelope. This envelope is now on display in the museum in Kilmainham jail. De Valera was a mathematician and greatly admired Hamilton. He lectured in mathematics in Maynooth during 191214. Stephen Buckley told me that, during the war of independence in 1920-21, some of the general public would say that De Valera was one of the few people in the world who understood what a quarter of onions were!

10. 1939 - On July 6, while introducing the Bill to establish the Dublin Institute of Advanced Studies, Taoiseach Éamon De Valera said in the Dáil, "This is the country of Hamilton, a country of great mathematicians".

11. 1939 - Hamilton's quaternions were mentioned in James Joyce's Finnegans Wake. The line is, "wondering was it hebrew set to himmeltones or the quicksilversong of qwaternions; his troubles may be over but his doubles have still to come". Hamilton was mentioned in at least two other places in Finnegans Wake. Sam Slote told me that Joyce is conflating Hamilton with two other Hamiltons in this line. James Archibald Hamilton was the first astronomer at Armagh Observatory and he observed the transit of Mercury, i.e. quicksilver. James Hamilton was a Scottish clergyman who published a book of psalms.

12. 1943 - Two stamps were produced to celebrate the centenary of Hamilton's creation of quaternions. Both the $2 \frac{1}{2} \mathrm{p}$ and $\frac{1}{2} \mathrm{p}$ stamps 
show the same picture of Hamilton and were designed by Sean O'Sullivan.

13. 1943 - Seán Keating painted a portrait of Hamilton. Éimear O'Connor, who has written a book on Keating, told me that it is unknown where this painting is. Éimear has never seen this portrait.

14. 1943 - Flann O'Brien (aka Myles na Gopaleen) commemorated the centenary of Hamilton's creation of quaternions with several references in his Cruiskeen Lawn piece in the Irish Times on June 18. In the references below, the house in Merrion Square is the Dublin Institute of Advanced Studies. The first mention of quaternions is in, "And what's the book about, says I. It's about quateernyuns, says the brother. That's a quare one". Two references appear in, "Of course all the brother's sums isn't done in the digs. He does be inside in a house in Merrion Square doin sums as well. If anybody calls, says the brother, tell them I'm above in Merrion Square workin at the quateernyuns, says he, and take any message. There does be other lads in the same house doin sums with the brother. The brother does be teachin them sums. He does be puttin them right about the sums and the quateernyuns". Another reference is in, "I do believe the brother's makin a good thing out of the sums and the quateernyuns. Your men couldn't offer him less than five bob an hour and I'm certain sure he gets his tea thrown in". A final reference appears in, "Begob the sums and the quateernyuns is quickly shoved aside when the alarm for grub is sounded and all hands piped to the table. The brother thinks there's a time for everything".

15. 1946 - Seán Keating painted a picture of Hamilton scratching the quaternion formulas on the bridge at Broombridge in Cabra. This painting is now in Dunsink Observatory. The painting was commissioned by Felix Hackett.

16. 1958 - On November 13, Taoiseach Eamon De Valera, unveiled a plaque at Broombridge to commemorate Hamilton's creation of quaternions. The unveiling received substantial coverage in the newspapers the following day. It appeared with a photograph on the front page of the Irish Times and was also prominently featured in the Irish Independent and Irish Press. De Valera started his speech with, "I am glad, as head of the Government, to be able to honour the memory of a great scientist and a great Irishman, It is a 
great personal satisfaction for me to be present, because it was well over fifty years ago since I had heard the story of the bridge and the birth of quaternions". De Valera also said, "On many occasions since I first heard this story I have come to this place as a holy place". See [4] for the rest of what De Valera said. Michael Biggs designed the plaque.

17. 1958 - The name of the bridge over the Royal Canal at Broombridge, where Hamilton scratched his quaternion formulas, was officially changed to Hamilton Bridge. See [4] for more details on this.

18. 1962 - Gerry Brady submitted a poem about Hamilton to the Irish Times and it was published on June 13.

19. 1963 - A crater on the moon was named after Hamilton.

20. 1970 - Annraoi de Paor told me that he named his son, Liam Ruán, after Hamilton.

21. 1974 - The local Fianna Fáil Cumann in Cabra West was called after Hamilton. Tom Breen told me that the idea for the name came from Vivion De Valera who was a local TD at the time. Vivion was a son of Éamon De Valera.

22. 1980 - Thomas Hankins wrote a biography of Hamilton [2].

23. 1983 - A stamp was produced as part of the Europa series which celebrated the great works of the human genius. It was a $29 p$ stamp and showed Hamilton's quaternion formulas. The stamp was designed by Peter Wildbur.

24. 1983 - Sean O'Donnell wrote a biography of Hamilton [7].

25. 1988 - Mike O'Regan set up the Hamilton Trust in England. Mike is a great-great grandson of Hamilton. The Hamilton Trust develops mathematics resources for teachers and students.

26. 1990 - Anthony G. O'Farrell initiated an annual walk to commemorate Hamilton's creation of quaternions. The walk takes place on October 16 and retraces Hamilton's steps by starting at Dunsink Observatory, where he lived, and ending up at Broombridge, where he created quaternions. The walk takes about forty-five minutes. I organise the walk now and it typically attracts about 200 people from a wide diversity of backgrounds, including many from the general public and second level schools. The large number of 
participants from the general public indicates that there is a substantial public interest in Hamilton and the walk. Furthermore, I receive many calls from the media (television, radio and newspaper) and other bodies every year expressing an interest in doing a piece on Hamilton and the walk. Consequently, Hamilton's story and the walk have appeared many times on a variety of television and radio programmes and in lots of newspaper articles. See [4] for more on the walk.

27. 1991 - Henry O'Brien asked James J. Cox to paint a portrait of Hamilton. The portrait is now on display at Broombridge during the annual Hamilton walk.

28. 1991 - David Simms coined the term, Broomsday, for October 16 because Hamilton created quaternions at Broombridge on that day. Coincidentally, Broomsday and Bloomsday are on the sixteenth (of different months).

29. 1992 - The Hamilton building opened in Trinity College and it contained the School of Mathematics.

30. 1995 - There was a reference to Hamilton's creation of quaternions in Act One of Sebastian Barry's play, The Only True History of Lizzie Finn. Sebastian e-mailed me to say that he saw the plaque at Broombridge while he was walking his dogs around 1990. He went on to write that there was something quite intoxicating about the plaque to him, especially marooned in the very altered landscape of that part of the northside - it put Hamilton on the path beside him, and he himself was forever scratching bits of speeches on scraps of paper when they occurred to him, stimulated by the walk, but usually without a handy pencil. The reference in the play appears when Robert says, "Can I tell you a very strange thing? William Rowan Hamilton, the mathematician, was walking along the Royal Canal near Finglas, puzzling the secret of quaternion multiplication, when suddenly a kingfisher came firing out of the green bank, like a blue bullet, a blue revelation. And in that moment of strange blue fire, jolted by it, it came to him: $i^{2}=j^{2}=k^{2}=i j k=-1$. And he scratched it hurriedly on the stone of the bridge nearby. Blue fire, Lizzie Finn, blue fire".

31. 1990s - Anthony O'Farrell put up a portrait of Hamilton in the Department of Mathematics at NUI, Maynooth. The portrait is a photograph of Sarah Purser's painting in the RIA above. 
32. 1997 - A new housing estate in Trim was named after Hamilton because he spent his early youth in Trim. The estate is called Hamilton Court. I suppose one could call Hamilton a meathamatician because of his Meath connections!

33. 1999 - LMFM (Louth Meath FM) radio asked me to do a show on Hamilton.

34. 1999 - Éigse na Mí (Meath heritage festival weekend) invited me to give a talk on Hamilton in Trim.

35. Annually since the 1990s - The Irish Times produces a piece that promotes the Hamilton walk. Dick Ahlstrom typically writes the piece based on my press release. Sometimes, other journalists write substantial pieces on Hamilton based on my interaction with them. For example, Arminta Wallace wrote a piece for An Irishwoman's Diary in the Irish Times in 2011. Other newspapers cover the walk from time to time. I also promote the walk on my annual radio show about mathematics on LMFM.

36. 2000 - Séamus MacGabhann of Ríocht na Midhe (Meath Archaeological and Historical Society) invited me to write a paper on Hamilton. The Society was interested in Hamilton because he spent his early youth in Trim, Co. Meath. The paper appeared in the annual journal [5].

37. 2001 - The Hamilton Institute at NUI, Maynooth was founded under the leadership of Robert Shorten and Doug Leith.

38. 2001 - Slane Historical Society invited me to give a talk on Hamilton.

39. 2001 - Gary McGuire and I wrote a paper about the walk and Hamilton [3].

40. 2002 - The Royal Irish Academy awarded an annual Hamilton Prize to mathematics students in nine of the Higher Education Institutions in Ireland. Each mathematics department is invited to nominate its best student in the penultimate year of undergradute study. The awards are presented to all the students as part of the RIA's Hamilton Day activities on or around October 16.

41. 2002 - The Royal Irish Academy initiated an annual public Hamilton lecture which occurs as part of its Hamilton Day activities on or around October 16. The lectures are given by internationally 
renowned speakers. Fields Medallists and Nobel Prize winners have been among those that have given the RIA Hamilton lecture. Luke Drury and Rebecca Farrell also usually bring the speaker on the Hamilton walk.

42. 2003 - Jack Gannon was inspired by the Hamilton walk to write a song called the Ballad of Rowan Hamilton. The song has been played many times on programmes about Hamilton and the walk on radio and television since then. See [4] for more details on the song.

43. 2003 - The Hamilton Mathematics Institute was founded at Trinity College.

44. 2003 - A television crew covered the Hamilton walk and the walk appeared on the Six One news on RTÉ 1 television that evening.

45. 2004 - A plaque was erected on the house in Trim where Hamilton spent his early youth. The house is called St. Mary's Abbey and is beautifully situated on the banks of the Boyne across from the spectacular ruins of Trim Castle. Peter Higgins now lives in the house and he put the plaque up after it was proposed by the National Committee for Science and Engineering Commemorative Plaques.

46. 2005 - The Government designated the year as Hamilton Year Celebrating Irish Science, because it was the bicentenary of Hamilton's birth. Many events were held all over Ireland to celebrate Hamilton year, some of which are listed below.

47. 2005 - On August 4 the Cabra Community Council celebrated Hamilton's birthday by organising a huge party and a barge trip along the Royal Canal.

48. 2005 - June Robinson wrote a poem about Hamilton called the Benefactor. See [4] for more on this.

49. 2005 - Léargas produced a thirty minute television documentary on Hamilton and it was shown on RTÉ 1 on November 14.

50. 2005 - A housing area in Cabra was named Rowan Hamilton Court. Hugh Flanagan and Liam O'Neill lobbied Dublin City Council to have the housing area named after Hamilton and they were successful.

51. 2005 - Cieran Perry and Henry O'Brien purchased, on behalf of the Cabra Community, a large banner in celebration of Hamilton. 
The idea for the banner was proposed by the Cabra Community Council. It creates a very festive atmosphere at the end of the Hamilton walk where it is draped across the bridge.

52. 2005 - The Central Bank of Ireland launched a new 10 euro collector's coin to celebrate the bicentenary of Hamilton's birth. The coin was designed by Michael Guilfoyle.

53. 2005 - An Post produced a Hamilton stamp to celebrate the bicentenary of Hamilton's birth. It was designed by Ger Garland.

54. 2005 - St. Declan's College, in Cabra, named one of its classes after Hamilton. It also awarded the new Hamilton coins to the students who obtained the best results in the Junior and Leaving Cert exams.

55. 2006 - Eoin Gill and Sheila Donegan of Calmast in Waterford IT founded Maths Week Ireland. The key day of the week is October 16 when Hamilton created quaternions. Consequently, Maths Week is always the week including October 16. The aim of Maths Week is to enhance the awareness, appreciation and understanding of mathematics among schoolchildren and the general public. Maths Week Ireland is now the most successful Maths Week in the world with over 200,000 participating directly in 2013.

56. 2006 - Mary Mulvihill's radio crew covered the Hamilton walk and it appeared on her radio show, Quantum Leap, on RTÉ 1 later in the week.

57. 2006 - Mick and Maureen Kelly founded a company called Science Heritage Ireland. Mick had participated in the 2005 Hamilton walk and he wrote, "That walk had a profound effect on me. Hearing not only a Nobel laureate and a professor of mathematics sing Hamilton's praises, but also local poets, school children, balladeers and the Cabra Community Council, spurred me to turn my desire to celebrate Ireland's Science Heritage into action. That action turned out to be a family run business called Science Heritage Ireland selling placemats and coasters celebrating Hamilton".

58. 2006 - Neville Henderson painted a picture of Hamilton scratching the quaternion formulas on the bridge and it was used in a brochure for the above Science Heritage Ireland company. Susan Waine also produced a design concept for the Hamilton placemat and coaster. 
59. 2007 and 2008 - Mick and Maureen Kelly set up a stall at Broombridge at the end of the Hamilton walk. They sold their Hamilton placemats and coasters mentioned above.

60. 2008 - Joey Burns created a bog oak sculpture in Trim with some of Hamilton's equations on it. Trim town council had commissioned a piece of art for Castle St. in the town. Joey told me that he was inspired by the Hamilton television documentary in 2005 above to create something related to Hamilton. His sculpture shows the salmon of knowledge rising from the water and reaching for the hazelnuts. Hamilton's equations lie in the waves near the base of the sculpture. In Celtic Mythology, the salmon gains all the world's knowledge when it eats the hazelnuts from the trees surrounding the well at the source of the River Boyne. The well is in Cairbre (aka Carbury in Co. Kildare) and the Boyne flows through Trim near the sculpture.

61. 2008 - Conn Ó Muineachain asked me to contribute a piece on Hamilton for a show on Raidió na Gaeltachta.

62. 2008 - James J. Cox painted his second portrait of Hamilton. This is also on display at Broombridge during the annual Hamilton walk.

63. 2009 - Joey Burns created several oak log benches along the banks of the Boyne in Trim. There are some lines from Hamilton's poetry on the benches. Trim Town Council had commissioned a piece of art for the banks of the river. Hamilton was also a poet and won the Chancellor's Prize twice in Trinity College and published his literary work in journals and magazines. Hamilton's motivation for doing mathematics was the quest for beauty. He once wrote, "Mathematics is an aesthetic creation, akin to poetry, with its own mysteries and moments of profound revelations". See [5] for more on Hamilton's poetry.

64. 2009 - Philip Bromwell asked me to appear on the Capital D programme on RTÉ 1 television. The show went out in early October in order to promote the annual walk and the Hamilton story.

65. 2009 - Eleanor Burnhill invited me to contribute to a radio piece about Hamilton and the walk. The piece appeared on Morning Ireland on RTÉ 1 on the morning of the walk. 
66. 2009 - There was a display related to Hamilton in the National Wax Museum which opened in Dublin.

67. 2009 - The South Fingal Heritage Society invited me to give a talk on Hamilton because of his Fingal connections.

68. 2009 - Elmgreen Golf Club created the Rowan Hamilton Singles Matchplay Trophy. The golf club is adjacent to Dunsink Observatory where Hamilton lived. Richard Wilson proposed that the trophy be named after Hamilton.

69. 2009 - Mick and Maureen Kelly produced T-shirts with the Quaternion formulas and a Hamilton slogan.

70. 2010 - In order to mark the twentieth anniversary of the Hamilton walk, I wrote a paper called Twenty Years of the Hamilton Walk [4]

71. 2010 - I was invited to appear on the Seán Moncrieff show on Newstalk radio to talk about Hamilton and to promote the Hamilton walk.

72. 2010 - A radio crew from Phoenix FM covered the walk and the show went out later in the week.

73. 2011 - Mary Mulvihill produced a one hour audio walking tour that was recorded during the Hamilton walk.

74. 2012 - Daniel Doyle created a giant sand sculpture that showed Hamilton scratching his quaternion formulas on the bridge in Cabra. The sculpture was in the courtyard of Dublin Castle as part of the annual exhibition of sand sculptures. The theme for the exhibition was Bright Sparks to coincide with the fact that Dublin was the European City of Science. Daniel chose Hamilton because his parents were from Cabra and they used to tell him the Hamilton story when he was young. Daniel is part of a trio of artists called Duthain Dealbh which means Fleeting Sculpture. They create ephemeral works of art for events all over the world using sand, ice and snow.

75. 2012 - Simone Corr was a student in the Dún Laoghaire Institute of Art, Design and Technology and she wanted to produce a work of art related to Hamilton as part of her student project. Simone contacted me and we collaborated on a video installation about Hamilton and mathematics. The piece was selected to appear 
in an exhibition called The Flaneur at the Olivier Cornet Gallery in Temple Bar in Dublin.

76. 2012 - Kathryn Maguire was creating a piece of art for the Five Lamps Festival in Dublin. She wanted to do something related to the Royal Canal. This led her to Hamilton. She contacted me and we discussed various ideas. Subsequently, Kathryn and her team produced some grafitti art which was on display along the Royal Canal at Croke Park during the festival. I thought graffiti art would be appropriate because Hamilton did his own graffiti when he scratched his quaternion formulas on the bridge. Hamilton's piece of mathematical vandalism would change the world of mathematics forever. Maurice O'Reilly also gave a talk along the canal as part of the festival.

77. 2012 - Des Gunning invited me to give a talk on Hamilton for Phizzfest which is the Phibsborough Community Arts Festival. They were interested in Hamilton because of his connection with the Royal Canal which passes through Phibsborough.

78. 2012 - John Coll sculpted a bust of Hamilton which is now in Ballinaclough House near Nenagh. Ballinaclough house is connected to Hamilton's wife, Helen Bayly, who was from the Nenagh area. Helen lived in another house nearby called Bayly Farm. Desmond Bayly, who lives in Bayly Farm, told me that Bayly Farm is the house where Hamilton and Helen spent their honeymoon. Desmond is related to Helen and the Bayly Farm Country House Accommodation website mentions the Hamilton connection.

79. 2012 - The sixteenth hole at Elmgreen Golf Club was renamed as the Rowan Hamilton Corner. Richard Wilson came up with this idea. Richard told me that this hole is unique in the world of golf because it's the only hole named after a mathematician! The golf club is adjacent to Dunsink Observatory where Hamilton lived.

80. 2012 - Eoin Gill and Sheila Donegan produced T-shirts with Hamilton's Icosian Game on them.

81. 2013 - There was an interview with me about the Hamilton walk on the Six One news on RTÉ 1 television, on the Nuacht on TG4 and on News Today on RTÉ 2 television.

82. 2013 - Iggy McGovern wrote a book of poetry called A Mystic Dream of 4 . The book comprises sixty four sonnets about the life 
and times of Hamilton. The sonnets are mainly in the voices of relatives, friends and colleagues of Hamilton.

83. 2013 - The Director of Poetry Ireland, Joe Woods, read a piece on Hamilton on the RTÉ 1 radio show, Sunday Miscellany. Joe had come on the walk previously.

84. 2014 - John Coll sculpted a bronze bust of Hamilton for the School of Mathematics, Statistics and Applied Mathematics in NUI, Galway. Aisling McCluskey told me that the school wanted to have a gallery of art and they commissoned John Coll to do the bust.

85. 2014 - Seán Duke invited me to contribute to an RTÉ radio 1 show called What's it All About. It was an hour long show about mathematics and Hamilton featured prominently.

\section{Some CuRRent items Related to Hamilton}

There always seems to be a variety of ongoing items related to Hamilton. Here are four current examples:

(a) Liam O'Neill and Jack Gannon have submitted proposals for the inclusion of Hamilton's name on the new Luas station at Broombridge. I plan to get more involved in the attempt to put Hamilton's name on the new station.

(b) The Kavaleer animation company contacted me because they were interested in producing an animated movie about Hamilton. They were aware that Hamilton's quaternions are important in computer animation and they wanted to kind of reverse that and do some computer animation on Hamilton himself!

(c) Dick Ahlstrom is writing a fictional novel based on Hamilton's life.

(d) Clare Tuffy from Newgrange has invited me to give a talk on Hamilton as part of Heritage Week later this year.

\section{REFERENCES}

[1] R. Graves: Life of Sir William Rowan Hamilton (in three volumes), 1882 1891.

[2] T. Hankins: Sir William Rowan Hamilton, Johns Hopkins University Press, 1980.

[3] G. McGuire and F. Ó Cairbre: A bridge over a Hamiltonian path, The Mathematical Intelligencer, Vol. 23, No. 3 (2001) 41-43. 
[4] F. Ó Cairbre: Twenty years of the Hamilton walk, Irish Mathematical Society Bulletin, No. 65 (2010), 33-49.

[5] F. Ó Cairbre: William Rowan Hamilton (1805-1865): Ireland's greatest mathematician, Ríocht na Midhe (Meath Archaeological and Historical Society), Vol. XI (2000), 124-150.

[6] F. Ó Cairbre: The power of the short story and the big picture in mathematics education in schools, universities and for the general public, Proceedings of the Third National Conference on Research in Mathematics Education, MEI3, St. Patrick's College, Drumcondra, (2009), 400-411.

[7] S. O'Donnell: William Rowan Hamilton, Boole Press, 1983.

Fiacre Ó Cairbre is a Senior Lecturer in Mathematics at NUI, Maynooth.

Department of Mathematics and Statistics, NUi, Maynooth

E-mail address: fiacre.ocairbre@nuim.ie 